\section{Comparação entre os Efeitos Hemodinâ- micos da Intoxicação Aguda com Bupiva- caína Racêmica e a Mistura com Excesso Enantiomérico de 50\% (S75:R25). Estudo Experimental em Cães}

(Rev Bras Anestesiol, 2006;56:391-401)

\section{Sra. Editora,}

Fazia-se necessária uma pesquisa que investigasse o anestésico local desenvolvido no Brasil sobre variáveis cardiocirculatórias na sua abrangência ${ }^{1}$.

Esse agente, estando difundido na prática anestesiológica, necessita de subsídios científicos para esclarecer sua farmacologia que deveria ter sido mais estudada na fase préclínica. Ao contrário, essa fase foi mal barateada por ser esse anestésico local oriundo da bupivacaína, cujas propriedades estão bem estabelecidas, embora continue sendo estudada até hoje, mesmo depois de quase meio século de sua síntese.

É de bom alvitre enfatizar que essa "bupivacaína modificada" está urgindo mais investigações laboratoriais, pois que deve ter perfil farmacológico peculiar e, destarte, amparar os anestesiologistas que a utilizam na busca da eficácia e da segurança, na pratica médica.

Todavia, em que pese a importância desse trabalho ${ }^{1}$, algumas considerações devem ser feitas, particularmente atinentes à história verdadeira do composto em defesa da nossa propriedade intelectual.

1. A mistura com excesso enantiomérico de $50 \%$ da bupivacaína 75:25 trata-se de um "anestésico local". Antes, porém, que suscite perplexidade em chamá-lo assim, cabe aqui a justificativa pela empáfia da denominação, "anestésico local”. Quando a bupivacaína racêmica foi resolvida (separada) e o isômero aproveitado, o esquerdo S(-) bupivacaína ou levobupivacaína foi considerado, de fato, um anestésico local e como tal assim permanece rotulado. Mas isto se permitiu, decerto, por ter acontecido no hemisfério norte mais precisamente em Cambridge, UK;

2. O desenvolvimento desse anestésico local teve sua autoria omitida, senão deturpada nesse trabalho de pesquisa em cães: a) a indústria farmacêutica NÃO sintetizou esse fármaco, absolutamente. Ele nasceu da manipulação enantiomérica dos componentes da bupivacaína racêmica. Houve impropriedade conceitual nesse artigo quando foi referido na discussão que a Indústria sintetizou o composto. Síntese, em processos industriais farmacêuticos, refere-se à obtenção de uma molécula nova por meio de química fina. A bupivacaína foi, na verdade, sintetizada pelo químico sueco Ekenstam, em 1957, partindo do esqueleto pipecolilxilidade que forneceu outros agentes, tais como a mepivacaína e a propivacaína. 0 arranjo dos radicais apensos ao esqueleto determinou a condição quiral, isto é, isomeria óptica, formando dois isômeros idênticos, mas com perfis farmacológicos distintos. Desta forma os enantiômeros apresentam per se propriedades farmacológicas próprias. Assim, a $\mathrm{R}(+)$ bupivacaína exerce maior afinidade pelos canais iônicos cardíacos e confere efeito bloqueador motor mais intenso do que sua antípoda ${ }^{2}$; b) estribados nessas evidências, realizamos um "malabarismo laboratorial" e misturamos os isômeros em proporções diferentes do racemado bupivacaína (S50:R50). Essa façanha aconteceu no Departamento de Farmacologia do Instituto de Ciências Biomédicas da Universidade de São Paulo em 1989 e está muito bem documentada científica ${ }^{3}$ e juridicamente. Um acordo formal, contudo, estabeleceu a cessão pela Universidade de São Paulo da tecnologia das novas composições enantioméricas à indústria que a adotou e produziu o composto (S75:R25) em escala industrial com insumos comprados no exterior (cloridratos de $\mathrm{S}(-)$ bupivacaína e de $R(+)$ bupivacaína), seguindo-se a sua comercialização depois de aprovada pela ANVISA;

3. A impropriedade conceitual que ora discuto sugere que esse trabalho de pesquisa, embora bem conduzido (e que nos coloca em pé de igualdade aos grandes centros de investigação mundiais), pecou pela falta de uma consulta mais ampla da literatura, inclusive estrangeira.

A conseqüência é que com os resultados obtidos que apontam ser a mistura enantiomérica S75:R25 mais cardiotóxica que a bupivacaína racêmica (os dados são explícitos), não se permite uma conclusão definitiva. O desconhecimento dos autores quanto aos ensaios com o composto S75:R25 que precederam esse estudo em cães impediu que os dados fossem cotejados com os de outras espécies, destarte, criando controvérsias quanto à cardiotoxicidade. De tal ordem que tais discrepâncias suscitaram o rótulo de "resultados intrigantes" - uma observação oportuna extraída do Editorial ${ }^{4}$. Senão vejamos:

a) Trachez e col. ${ }^{5}$ conduziram uma pesquisa básica muito criteriosa e demonstraram que a dose letal para os ratos foi respectivamente: $39,9 \mathrm{mg} \cdot \mathrm{kg}^{-1}$ para S75:R25; $34,7 \mathrm{mg} \cdot \mathrm{kg}^{-1}$ para $\mathrm{S}(-)$; $16,2 \mathrm{mg} \cdot \mathrm{kg}^{-1}$ para $\mathrm{R}(+)$ e $18.4 \mathrm{mg} \cdot \mathrm{kg}^{-1}$ para bupivacaína racêmica. Portanto, a mistura S75:R25 precisa de uma dose maior do que a da bupivacaína racêmica para sacrificar os ratos. Logo, conclui-se pela menor toxicidade daquela. Este estudo referenda o nosso ${ }^{6}$, também em ratos in vivo, no qual os parâmetros hemodinâmicos (pressão arterial média e freqüência cardíaca) sugerem menor cardiodepressão do composto $S 75: R 25$, com relação à bupivacaína racêmica e ao isômero puro $R(+)$ bupivacaína. Enquanto seus efeitos foram IGUAIS aos da S(-) bupivacaína (levobupivacaína) em termos dessa depressão. b) Por outro lado, não foram Gonçalves e col. ${ }^{7}$, conforme referidos na discussão, que reclamaram da necessidade do isômero $R(+)$ para que se conseguisse bloqueio motor suficiente para o ato cirúr- 
gico. Esta evidência veio à tona com Mathias ${ }^{8}$, quando ensaiou a levobupivacaína e nos confidenciou a famosa frase: "O anestésico local para ser bom precisa ser tóxico." Esta foi a conclusão que ele chegou frente à ineficiência do bloqueio neuromuscular nos procedimentos cirúrgicos abdominais sob a técnica peridural realizada com levobupivacaína (o isômero $\mathrm{S}(-)$ bupivacaína puro).

Então, aproveitamos essa inferência inteligente e racional e, embasados na literatura, manipulamos os componentes isoméricos da bupivacaína, visando a atingir dois alvos: a toxicidade e o bloqueio motor. Reduzindo a proporção do componente cardiotóxico, a $\mathrm{R}(+)$ bupivacaína, e aumentando a $\mathrm{S}(-)$ bupivacaína. O composto resultante diminuiu a toxicidade da bupivacaína racêmica e corrigiu a ineficiência do bloqueio neuromuscular tão reclamado com a utilização da levobupivacaína.

Foi assim obtido um "racemado específico", na medida em que entram na composição dois isômeros. Esse conceito "racemado específico" vem sendo sugerido modernamente, embora fugindo da designação clássica do racemado (já consagrado), para a proporção de 1:1 das substâncias isoméricas. Todavia, o novo conceito deve ser levado em consideração, na era da estereoisomeria, na qual outras alterações racêmicas podem vir a acontecer.

A mistura enantiomérica da bupivacaína é o resultado, portanto, da modificação das proporções dos isômeros da bupivacaína racêmica.

Os novos compostos foram estudados em ratos in vivo na preparação nervo ciático e estudados parâmetros cardiocirculatórios cotejando os três anestésicos locais: S75:R25, levobupivacaína e bupivacaína racêmica e o isômero $\mathrm{R}(+)$ bupivacaína ${ }^{3,6}$. Esses estudos foram referendados por Trachez e col. na mesma preparação, tendo demonstrado ser a potência bloqueadora do composto S75:R25, 25\% maior do que a $\mathrm{S}(-)$ bupivacaína (levobupivacaína) enquanto a toxicidade diferiu estatisticamente da bupivacaína racêmica, conforme já discutido.

Por oportuno, cabe mencionar que os resultados em cães encontrados nessa investigação contrapõem-se aos que foram publicados na literatura. Sob o ponto de vista teórico e investigativo, essa controvérsia merece estudos complementares envolvendo: a) eletrofisiologia cardíaca; b) farmacocinética (não encontramos menção ao equipamento utilizado para a injeção dos anestésicos locais e a velocidade dessa injeção; c) reavaliação do tratamento estatístico. Deste modo, seriam esclarecidos os "resultados intrigantes" que surpreenderam tanto os autores como também o editorialista ${ }^{1,4}$. Acrescente-se, ainda, a importância da inclusão da S(-) bupivacaína pura (levobupivacaína) numa futura investigação, pois daria subsídios para confirmar ou infirmar a hipótese da existência de "modulação nas ligações dos enantiômeros com os seus sítios de ação anestésica" 5 .

O trabalho de Udelsmann e col. ${ }^{1}$, contudo, tem méritos com relação ao método altamente sofisticado e conduzido em animais de grande porte, embora Kasten e Martin ${ }^{9}$, que se notabilizaram com os estudos sobre toxicidade da bupivacaína nos primórdios, preferissem a experimentação em ovelhas devido à similitude aos humanos, quanto a alguns aspectos fisiológicos.

Finalizando, cumprimento os autores, parafraseando dois grandes pesquisadores Mather e Chang ${ }^{10}$ : "Os agentes mais novos devem ser vistos como mais seguros, mas eles nunca devem ser considerados seguros...".

Atenciosamente,

Maria P. B. Simonetti, TSA, M.D.

Professora Doutora

Departamento de Farmacologia

- Instituto de Ciências Biomédicas

Universidade de São Paulo

\section{Comparing the hemodynamic effects of acute intoxication with racemic bupiva- caine and with $50 \%$ enantiomeric excess mixture (S75:R25). An experimental study in dogs.}

(Rev Bras Anestesiol, 2006;56:391-401)

\section{Dear Editor,}

There was a need for a study that investigated the cardiocirculatory effects of the local anesthetic developed in Brazil ${ }^{1}$.

Since this agent is widely used in anesthesiology, it needed scientific support to explain its pharmacology, which should have been done in the pre-clinical phase. But this phase was not fully explored because this anesthetic derived from bupivacaine, whose properties are well known although, even after almost half a century, it is still being studied.

Note that this "modified bupivacaine" needs further laboratory investigation, because it probably has a unique pharmacological profile, to give support to anesthesiologists that use it looking for greater efficacy and safety in their practice.

However, despite the significance of this study ${ }^{1}$, a few observations, especially concerning the real story of this agent to defend our intellectual property, should be made.

1. The 75:25 enantiomeric mixture of bupivacaine is a "local anesthetic". But before one is appalled by my calling it so, it is necessary to explain why the denomination "local anesthetic". When racemic bupivacaine was separated, the isomer that was used, the left (S-) bupivacaine, or levobupivacaine, was considered a local anesthetic and as such has remained so. But that was possible because it happened in the northern hemisphere, more precisely in Cambridge, UK;

2. This study in dogs suppressed, if not misrepresented, the authorship of this local anesthetic: a) the pharmaceutical 
industry DID NOT synthesize this drug. It arose from the enantiomeric manipulation of the components of racemic bupivacaine. This report incurred in a conceptual error when, in the discussion, it mentioned that the industry synthesized the drug. In the pharmaceutical industrial process, synthesis refers to the production of a new molecule by means of fine chemistry. In reality, bupivacaine was synthesized in 1957 by the Swedish chemist Ekanstam from the pipecolylxylidine skeleton that gave rise to other agents. The distribution of the radicals attached to the skeleton determined the chiral condition, i.e., the optical isomer, forming two identical isomers with distinct pharmacologic profiles. Therefore, each enantiomer presents unique pharmacologic properties. Thus, $R(+)$ bupivacaine has more affinity for cardiac ion channels and more motor blockade that its antipodal ${ }^{2}$; b) based on this evidence, we performed a "laboratorial juggling act" and mixed the isomers in amounts that differ from racemic bupivacaine (S50:R50). This happened in 1989 in the Pharmacology Department of the Instituto de Ciências Médicas da Universidade de São Paulo, and is well documented, both scientifically an legally ${ }^{3}$.

But a formal agreement transferred the technology of the new enantiomeric compounds from the Universidade de São Paulo to the Industry that adopted and produced the compound (S75:R25) in industrial scale with raw materials bought abroad (chloridate of $S(-)$ bupivacaine and chloridate of $\mathrm{R}(+)$ bupivacaine), which was commercialized after approval by ANVISA;

3) The conceptual impropriety that I argue here suggests that, although this study was well done (placing us on the same level as other large international research centers), it erred in not making a deeper literature search.

The results suggest that the enantiomeric mixture S75:R25 is more cardiotoxic than racemic bupivacaine (the data are explicit) but do not allow for a definitive conclusion. The lack of knowledge of the authors about the assays with the $\mathrm{S} 75: \mathrm{R} 25$ compound that preceded this study in dogs hampered the comparison between their results with those done in other species, raising controversy about the cardiotoxicity. As such, the discrepancies gave rise to the label "intriguing results" - a convenient observation taken from the Editorial ${ }^{4}$. Consider this:

a) Trachez et al. ${ }^{5}$ undertook a judicious study and demonstrated that the lethal dose for rats was: 39.9 mg. $\mathrm{kg}^{-1}$ for S75: R25; 34.7 mg. kg ${ }^{-1}$ for $\mathrm{S}(-)$; 16.2 mg. $\mathrm{kg}^{-1}$ for $\mathrm{R}(+)$; and 18.4 $\mathrm{mg} . \mathrm{kg}^{-1}$ racemic bupivacaine. Therefore, it is necessary a higher dose of the S75:R25 mixture than racemic bupivacaine to kill the rats. Consequently, one can conclude that the former is less toxic. That study confirms our results ${ }^{6}$, which was also done in vivo in rats, in which the hemodynamic parameters (mean arterial pressure and heart rate) suggest that S75:R25 causes less cardiac depression than the racemic compound and the pure $(\mathrm{R}+)$ bupivacaine. But its effects, concerning this depression, were THE SAME as S(-) bupi- vacaine (levobupivacaine). b) Contrary to what is stated in the discussion, it was not Gonçalves et al. ${ }^{7}$ who indicated the need for the $\mathrm{R}(+)$ isomer to achieve a good motor blockade for surgical procedures. It was Mathias ${ }^{8}$ in his study of levobupivacaine who said: "to be good, a local anesthetic has to be toxic". It was his conclusion when he was faced with the inefficient neuromuscular blockade of the epidural block with levobupivacaine (the pure $\mathrm{S}(-)$ isomer) in abdominal surgeries.

Thus, taking advantage of this bright and rational inference supported by the literature, we manipulated the isomeric components of bupivacaine with two objectives: toxicity and motor blockade. Reducing the proportion of the cardiotoxic component, $\mathrm{R}(+)$ bupivacaine, and increasing the proportion of $\mathrm{S}(-)$ bupivacaine, the resulting compound reduced the toxicity of racemic bupivacaine and corrected the ineffective neuromuscular blockade.

A "specific racemism" was then obtained, since it has two isomers in its composition. This concept of "specific racemism" has been suggested lately, although it does not have the classic meaning of racemism, of a 1:1 proportion of the isomeric forms. However, the new concept should be considered, in this era of stereoisomerism, where there might be other racemic changes.

Therefore, the enantiomeric mixture of bupivacaine results from changing the proportion of the isomers of racemic bupivacaine.

The cardiocirculatory parameters of the new compounds were studied in vivo, in rats, in the sciatic nerve preparation, analyzing the 3 local anesthetics: S75:R25, levobupivacaine, and racemic bupivacaine and the isomer $R(+)$ bupivacaine ${ }^{3,6}$. These studies were corroborated by Tranches et al., who showed that the blocking potency of S75:R25 is $25 \%$ greater than that of S(-) bupivacaine (levobupivacaine), while the toxicity was significantly different from racemic bupivacaine.

It should be mentioned that the results of this study in dogs disagree from those reported in the literature. This controversy deserves further studies regarding: a) cardiac electro physiology; b) pharmacokinetics (there was no mention about the equipment used to inject the local anesthetics and the rate of the injection); c) reevaluation of the statistical analysis. That would elucidate the "intriguing result" that startled not only the authors but also the editorialist ${ }^{1,4}$. It is important to include the pure $\mathrm{S}(-)$ bupivacaine (levobupivacaine) in future studies, since it would confirm or weaken the hypothesis that there is "modulation in the connection of the enantiomers with their sites of action" 5 .

However, the study of Udelsmann et al. ${ }^{1}$ deserves credit regarding the highly sophisticated methodology in large animals, although Kasten and Martin ${ }^{9}$, renowned for their studies on the toxicity of bupivacaine, prefer to work with sheep due to their similarity with human beings regarding some physiological characteristics. 
Finally, I congratulate the authors paraphrasing two great researchers, Mather and Chang 10: "the newer agents should be considered safer, but they should never be considered safe..."

Sincerely,

Maria P. B. Simonetti, TSA, M.D.

Professor/Physician

Pharmacology Department

- Instituto de Ciências Biomédicas

Universidade de São Paulo

\section{REFERÊNCIAS - REFERENCES}

01. Uldelsmann A, Munhoz DC, Silva WA et al - Comparação entre efeitos hemodinâmicos da intoxicação aguda com bupivacaína racêmica e a mistura com excesso enantiomérico de $50 \%$ (S75:R25). Estudo experimental em cães. Rev Bras Anestesiol, 2006;56:4:391-401.

02. Vladimirov M, Nau C, Mok WM et al - Potency of bupivacaine stereoisomers tested in vitro and in vivo. Biochemical, electrophysiological, and neurobehavioral studies. Anesthesiology, 2000;93:744-755.

03. Simonetti MPB, Ferreira FM - Does the D-isomer of bupivacaine contribute to improvement of efficacy in neural block. Reg Anesth Pain Med, 1999;24:(3/Suppl):43.

04. Torres MLA - Toxicidade dos anestésicos locais: o debate continua! Rev Bras Anestesiol, 2006;56:339-342.

05. Trachez MM, Zapata-Sudo, Moreira OR et al - Motor nerve blockade potency and toxicity of non-racemic bupivacaine in rats. Acta Anaesthesiol Scand, 2005:49:66-71.

06. Simonetti MPB, Ferreira FMC, Ferreira $\mathrm{Jr} \mathrm{R}$ et al - Is it worth manipulating the enantiomeric ratio of bupivacaine to improve the efficacy of the neural block with reduced cardiotoxicity? Inter Monitor, 1999;11: (Suppl):196.

07. Gonçalves RF, Lauretti GR, Mattos AL - Estudo comparativo entre bupivacaína a $0,5 \%$ e mistura enantiomérica de bupivacaína (S75:R25) em anestesia peridural. Rev Bras Anestesiol, 2003;53:169-175.

08. Mathias RS - Levobupi: uma nova opção de anestésico local com menor cardiotoxicidade. Rev Bras Anestesiol, 1997 ;47:(Supl22): CBA.

09. Kasten GW, Martin ST - Bupivacaine cardiovascular toxicity: comparison of treatment with bretylium and lidocaine. Anesth Analg,. 1985,64:911-916.

10. Mather LE, Chang DH - Cardiotoxicity with modern local anaesthetics: is there a safer choice? Drugs, 2001:61:333-342.

\section{Réplica}

\section{Sra. Editora,}

A colega missivista está certa: a indústria produziu, distribuiu e comercializou o fármaco. No que tange à sua autoria, não foi ele objeto de nosso trabalho, não tendo assim sido omitido e nem deturpado, mesmo porque, se há como informado um embate jurídico sobre a questão, leigos têm muito mais interesse ainda em se manter afastados do problema. A Dra. Simonetti realmente apresentou um trabalho interessante sobre misturas enantioméricas, cujo resumo está publicado na Regional Anesthesia and Pain Medicine, 1999;24(3/Suppl):43 e tem por essa razão seu mérito, tal não tira o do nosso laboratório que encontrou realmente "resultados intrigantes" ", porém reais, e que por isso devem ser discutidos. Gonçalves e col. ${ }^{2}$ afirmaram na discussão de seu artigo a possibilidade da introdução de $25 \%$ do isômero R-bupivacaína melhorar o perfil anestésico da formulação, isso não se contrapõe a que Mathias já tivesse afirmado isso anteriormente, mas a tal não tivemos acesso. Realmente, nossos resultados contrariam os achados da literatura, mas isso também deve ser visto com alguma reserva, pois trabalhos semelhantes utilizaram sempre a Lbupivacaína e não a mistura enantiomérica. Mesmo assim, algumas publicações recentes já têm colocado em evidência ${ }^{3,4}$ em animais uma maior cardiotoxicidade do isômero levógiro puro. O tempo de injeção do anestésico foi padronizado em 30 segundos e a estatística, realizada pelo Serviço de Bioestatística da Câmara de Pesquisa da FCMUNICAMP. Intrigados com nossos resultados, realizamos outra pesquisa semelhante, desta vez em suínos pela sua semelhança fisiológica com humanos no que tange ao aparelho cardiovascular e utilizando agora a bupivacaína racêmica, a mistura enantiomérica e a levobupivacaína. Esses resultados foram apresentados no $52^{\circ}$ Congresso Brasileiro de Anestesiologia, constam dos anais (CBA 163) e esperamos que sejam publicados na Revista Brasileira de Anestesiologia para contribuirmos ainda mais para o debate sobre anestésicos locais.

$$
\begin{aligned}
& \text { Artur Udelsmann } \\
& \text { FCM - UNICAMP }
\end{aligned}
$$

\section{Reply}

\section{Dear Editor,}

My dear colleague is right: the industry produced, distributed, and commercialized the drug. Its authorship was not the focus of our study; therefore, it was neither suppressed nor distorted. But, if this matter is object of a legal battle, lay people should keep a distance. Dr. Simonetti did present an interesting study on enantiomeric mixtures, whose summary is published in Regional Anesthesia and Pain Medicine, 1999;24(3/Suppl):43 and, for this reason, should be respected. This does not diminish our laboratory that really found "intriguing results", but real results, which should be discussed. Gonçalves et al. ${ }^{2}$, in the discussion of their paper, indicated the possibility that the introduction of $25 \%$ of Rbupivacaine could improve the anesthetic profile of the drug. This does not go against what Mathias stated previously, but we did not have access to it. Our results were really the 
opposite of those reported in the literature, but one should be careful because similar works always used L-bupivacaine and not the enantiomeric mixture. But some recent reports ${ }^{3,4}$ indicated a greater cardiotoxicity of the pure levorotatory isomer in animals. The anesthetic was injected in 30 seconds, which was the standard duration, and the statistical analysis was done by the Serviço de Bioestatística da Câmara de Pesquisa da FCM - UNICAMP. Intrigued with our results, we did another study in pigs, due to their physiologic similarity with human beings concerning the cardiovascular system, and this time we used racemic bupivacaine, the enantiomeric mixture, and levobupivacaine. Those results were presented in the $52^{\circ}$ Congresso Brasileiro de Anestesiologia, were included in the annals (CBA 163), and we hope will be published in the Revista Brasileira de Anestesiologia to contribute even more to the debate on local anesthetics.

\section{REFERÊNCIAS - REFERENCES}

01. Torres MLA - Toxicidade dos anestésicos locais: o debate continua. Rev Bras Anestesiol, 2006;56:339-342.

02. Gonçalves RF, Lauretti GR, Mattos AL - Estudo comparativo entre bupivacaína a 0,5\% e mistura enantiomérica de bupivacaína (S75-R25) a 0,5\% em anestesia peridural. Rev Bras Anestesiol, 2003;53:169-176.

03. Masuda R, Takeda S, Yoshii S et al. - Levobupivacaine exerts the most detrimental effect on the cardiovascular system among enantiomers of bupivacaine in anesthetized dogs - Anesthesiology, 2004;101:(Suppl):A652

04. Jung CW, Lee KH, Choe YS et al. - Comparison of resuscitative effect of insulin between bupivacaine and levobupivacaine induced cardiovascular collapse in dogs. Anesthesiology, 2004; 101:(Suppl):A649
Artur Udelsmann

FCM - UNICAMP 